\title{
Effect of Age Hardening Conditions on Mechanical Properties of AW 6082 Alloy Welds
}

Jaromír Moravec, Iva Nováková, Josef Bradáč

Technical University of Liberec. Studentská 2, 46117 Liberec 1. Czech Republic. E-mail: jaromir.moravec@tul.cz, iva.novakova@tul.cz,josef.bradac@tul.cz

The present paper expands the knowledge in the field of welding of age hardening aluminium alloys using MIG method. Aluminium alloy AW 6082 (AlSi1MgMn) according to the specification standard CSN 424400 was used for the experiment. This type of alloy is used in industrial practice e.g. for medium stressed parts in railway and motor vehicles and in water, oil or petrol pipes. For the purpose of assessing the impact of multiple cycles on the properties in the heat affected zone the weld was designed as a multi-layer weld. The objective of this paper is not only the impact assessment of the degradation of the mechanical properties, but also the possibility of recovery of these properties by heat treatment. During the experiment, the effect of temperature holding time by solution annealing and artificial hardening on the mechanical properties of the base material, HAZ and weld was studied. The effect of heat treatment was evaluated by Vickers hardness test.

Keywords: AW 6082, welding, heat treatment

\section{Acknowledgement}

This paper was written at the Technical University of Liberec with the support of the Specific University Research Grant SGS, as provided by the Ministry of Education, Youth and Sports of the Czech Republic in the year 2016.

\section{References}

[1] MICHNA, Š. et al. (2005). Aluminium Encyclopedia. pp. 119 - 228. Prešov: ADIN. ISBN 80-89041-88-4.

[2] Composite Authors. (2001). Materials and their Weldability. pp. 233 - 240. Ostrava: ZEROSS. ISBN 80-8577185-3.

[3] SAHUL, M., TURŇA, M., ŠUGÁROVÁ, J., SAHUL, M. (2013). Influence of laser welding aluminium alloy on mechanical properties of welded joints. In: Manufacturing Technology, Vol. 13, No. December 2013, pp. 526 530.

[4] KOPAS, P., SÁGA, M. (2013). In-phase multi-axial fatigue experimental analysis of welded cylindrical 6063-T66 aluminium alloy specimens. In: Manufacturing Technology, Vol. 13, No. March 2013, pp. 59 - 64.

[5] BAYAZID, S.M. et al. (2016). Effect of cyclic solution treatment on microstructure and mechanical properties of friction stir welded $7075 \mathrm{Al}$ alloy. In: Materials Science and Engineering A, Vol. 649, No. January 01, pp. 293 300.

[6] CHEN, Y. et al. (2016). Influence of multi-pass friction stir processing on the microstructure and mechanical properties of Al-5083 alloy. In: Materials Science and Engineering A, Vol. 650, No. January 05, pp. 281 - 289.

[7] SHIRAZI, H., KHEIRANDISH, S., SAFARKHANIAN, M.A. (2015). Effect of process parameters on the macrostructure and defect formation in friction stir lap welding of AA5456 aluminium alloy. In: Journal of the International Measurement Confederation, Vol. 76, No. 12 December 2015, pp. 62 - 69.

[8] HAN, Y., ZHANG, S., PANG, S., HONG, H. (2015). Arc behaviour during variable polarity TIG welding of aluminum alloy. In: Hanjie Xuebao/Transactions of the China Welding Institution, Vol. 36, Issue 9, No. 25 September 2015, pp. 51-54 and 59.

[9] KOLÁř́, V. Weldability of aluminium alloys [online]. [cite 2015-10-25]. Available from www: <http://www.cwsanb.cz/t.py?t=2\&i=502>.

[10]ČSN EN 515. Aluminium and its alloys - Formed products - Identification of states. Praha: Czech standard institute, 1995. 22 p. Class number: 420053.

[11]MORAVEC, J. (2014). Three layer butt weld of AW 6082. TUL-Z-14-VS-AW6082-01, TU Liberec, Liberec, pp. 2-27.

[12]MORAVEC, J. (2014). Hardness measurement HV 10 in base material, HAZ and weld metal for three-layered weld made of Al6082 alloy. TUL-Z-AW6082-MT-01, TU Liberec, Liberec, pp. 2-27.

[13]MORAVEC, J. (2014). Hardness measurement HV 10 in base material, HAZ and weld metal for three-layered weld made of Al6082 alloy after age hardening. TUL-Z-AW6082-TZ-MT-01, TU Liberec, Liberec, pp. 2-25. 